Magyar Honvédség Egészségügyi Közpon Neurológiai Osztály

\title{
Paraszomniák és alvás alatti epilepsziák jelentősége és differenciál-diagnosztikája
}

\author{
Dr. habil Szakács Zoltán orvos ezredes, PhD
}

Kulcsszavak: paraszomnia, epilepszia, poliszomnográfia, alvásfüggő mozgászavarok

A szerző a diferenciál-diagnosztikai szempontból jelentős nehézséget okozó alvásfüggő mozgászavarokat mutatja be, kiemelve a paraszomniák és alvás alatti epilepsziák szerepét. Az alvás alatt a mozgás-megnyilvánulások széles skálája alakulhat ki, a fiziológiás alvási mozgásjelenségek (mint a testhelyzet-változtatás) mellett számtalan kóros mozgásforma is. Számos esetben nehézséget okoz az egyes mozgásjelenségek eredetének megítélése. A legfontosabbak az alvászavarokhoz tartozó formák (paraszomniák, nyugtalan láb szindróma stb.), a mozgászavarok alvás alatti jellegzetességei, valamint az epilepsziás müködészavar talaján kialakuló formák. A kivizsgálás magában foglalja a mozgástöbblet speciális szempontok (többek között a jelenség időzítésének, ismétlődésének, lezajlási mintázatának és esetleges provokáló faktorok ismeretének) alapján való jellemzését, poliszomnográfiás és videó-EEG monitorozást, valamint validált kérdőívek (pl. FLEP skála) használatát. A megfelelő differenciál-diagnosztika és terápia az alvás alatti események, alvás szerkezet és mozgástöbbletek összefüggéseinek ismerete alapján lehetséges.

Felnőtt embernek fizikai és szellemi igénybevételétől függően 6-8 óra alvásra van szüksége. Ennek az időnek 20-20 százalékát teszi ki az ún. lassú hullámú alvás, illetve az ún. álomfázis. Előbbi az idegrendszer és az egész szervezet regenerációjának ideje, utóbbi alatt szellemi működésünk szerveződik át, fejlődik tovább. Ismert irodalmi adat, hogy a NASA kutatói kimutatták, 20 év körüli katonáknak minimálisan napi 4,5 órás alvásra volt szüksége ahhoz, hogy még az elöírt teljesítményszintnek 5 napon keresztül meg tudjanak felelni. Az ilyenkor észlelt alvás fele-fele arányban e két „életfontosságú" alvásformából állt. Az egyéb szempontból igen jelentős átmeneti alvásszakaszok gyakorlatilag eltüntek. Ismert az is, hogy ez a jó alkalmazkodóképesség későbbi életkorokban rohamosan csökken, alvásunk összetétele változik és elmerevedik. 
Az utóbbi évtizedekben ismerte fel és hasznosítja mind nagyobb mértékben az orvostudomány, hogy az életünk közel egyharmadát kitevő alvás fontos tényező életmüködéseink szerveződésében, testi-lelki egészségünk és teljesítményünk fenntartásában. A katonai szolgálathoz számos vonatkozásban kapcsolódó többmüszakos munkakörök különböző változatai, a megszokott alvás-ébrenlét ritmust változtathatják meg szintén alvásképtelenséget okozva. Új diagnosztikai módszerek és terápiás lehetőségek jöttek létre az alvás-és éberség zavarok vizsgálatára, kezelésére és megelőzésére.

$\mathrm{A} z$ alvás ép és kóros viszonyainak tudományosan megalapozott vizsgálatára, szürésére és kezelésére mind nagyobb igény mutatkozik. A világ számos országában - nem egyszer a katonaegészségügy meghatározó részvételével - alakult ki a tudományos alapkutatást, illetve a klinikai gyógyító-megelőző tevékenységet folytató szakembergárda, alvásdiagnosztikai központok, kutatóhelyek szerveződtek.

$\mathrm{Az}$ alvászavarok és alvásbetegségek terén összegyűlt sok tapasztalat természetesen csak akkor értékesíthető a katonai és katasztrófaorvostan területén, ha gyakorlattá válik. Egyik fö célunk volt, hogy MH Egészségügyi Központ Neurológiai osztálya Alváslaboratóriumában egyik fő szakmai és tudományos témájává tegyük az ide tartozó kórképek diagnosztizálását, kezelését, szürésének megszervezését. Ennek érdekében öszszeállítottuk az alvásfüggő mozgás- és légzészavarok, a hiperszomniák, illetve a paraszomniák kivizsgálásának és kezelésének protokolljait, amelyek meghatározzák az alapellátásban (csapatorvosi, háziorvosi rendelők), valamint kórházunk szakambulanciáján és egyes esetekben az osztályon szükséges teendőket. A katonai egészségügyben müködő alvásdiagnosztikai laboratóriumnak feladata kiszürni a speciális több müszakos körülmények közötti teljesítő katonákból a disszomniában szenvedőket, továbbá felismerni az éjszakai mozgászavarok katonai szolgálatot veszélyeztető formáit.

$\mathrm{Az}$ alvás során jelentkező mozgászavarok mögött számtalan kórkép húzódhat meg. Kivizsgálásuk és kezelésük egységes szemléletet igényel, melyhez hozzá tartozik az alvás szerkezetének, szabályozásának és a disszociációs jelenségek ismerete, az alvás során kialakuló mozgástöbblettel, vagy éppen annak csökkenésével járó állapotok egyes alvásfázisokkal való kapcsolata, valamint ezek kölcsönhatása [1].

A napi gyakorlat szempontjából a két legfontosabb csoport, a paraszomniák és az alvás alatti epilepsziák számos ponton átfedést mutatnak. A mozgás-megnyilvánulások nem mindig egyértelműek, EEG korrelátum nem minden esetben áll rendelkezésre.

Számos klasszikus alvászavart (pl. alvásfüggő légzészavarokat) változatos mozgásjelenségek kísérhetnek, amelyek összekeverhetők akár epileptogén eredetüvel, akár egyéb kórfolyamat következtében kialakulttal.

$\mathrm{Az}$,egyszerü” alapelvek ellenére az egyes kóros mozgás-megnyilvánulások korrekt elemzése, értékelése jelentős kihívást képvisel. Ugyanazon jelenség megítélése nagyban eltér különböző kiértékelők és vizsgálók között [2].

A fentiek miatt érdemes áttekinteni az egyes fontosabb mozgásjelenségeket és alapvető differenciál-diagnosztikai lehetőségeket és összefüggéseit.

\section{Alvás alatti mozgástöbblet}

Az alvás alatti mozgás-megnyilvánulások jelentős differenciál-diagnosztikai kihívást képviselnek, részben a mögöttes 
patológia, részben a megjelenési forma sokszínűsége miatt. Számos alvászavar jár mozgástöbblettel [3]. Emellett az alvás során megjelenő epilepsziák képezik az elkülönítés fö irányait, nehézségeit. A legfontosabb alvás alatti mozgástöbbletek közé tartoznak a paraszomniák, a nyugtalan láb szindróma, periódikus végtagmozgás-zavar betegség, az alvásfüggő légzészavarok során kialakuló mozgások, az epileptogén eredetű jelenségek. A legfontosabb képviselöket az I. táblázat foglalja össze [4].

Alvásfüggő légzészavarok esetén a túlmozgást a légzéskihagyást kísérő hipoxia és a (többek között) ennek következtében kialakuló patológiás mikroébredés indukálja. A mozgás-megnyilvánulásra jellemző a nagy, tömeges, csapkodó, forgolódó mozgás, amely látványos, a hálótárs által észlelt, akár sérülésekig vezető (ágyról leesés, alvótársban okozott sérülés) lehet [3].

Az obstruktív alvási apnoe betegség esetén a horkolás jellege fontos differenciál-diagnosztikai adalék, azonban számos esetben (centrális apnoe, CheyneStokes légzés, alvás alatti hipoventilláció) a horkolás hiányzik, de a deszaturációkat, mikroébredéseket kísérő mozgástöbbletek hasonlóan kifejezettek lehetnek, mint a garatelzáródásos típusban.

\section{I. táblázat. Alvással, vagy ébredéssel} kapcsolatos epilepsziák

- Rolandikus epilepszia

- Frontális epilepszia hypermotoros rohamokkal

- Juvenilis mioklónusos epilepszia

- Absence epilepszia

- Ébredési generalizált tónusos-klónusos rohamok

- Epilepsziás encefalopátiák

- Lennox-Gastaut szindróma

- Folyamatos "spike and wave” epilepszia alvásban (CSWS)

- Egyéb
A differenciál-diagnosztikában a video-poliszomnográfiás vizsgálatnak van szerepe - akár 16-32 csatorna EEG regisztrálási lehetőséggel.

\section{Az éjszakai mozgástöbbletek fajtái}

Az alvás alatti mozgástöbblet egy meglehetösen heterogén csoport, számtalan képviselővel [4]. Azonban nem minden mozgolódásunk kóros. Az éjszaka folyamán fiziológiás alvási mozgásjelenség a testhelyzetváltozás, melynek a legkézenfekvőbb értelme a nyomásnak kitett felületek és területek védelme. Jellegzetes mozgás-megnyilvánulás az elalvás fázisában a megfelelő alváspozíció megtalálása is.

A kóros mozgás-megnyilvánulások sokkal szélesebb, nagyobb csoportot alkotnak. Amennyiben a megjelenési formát vizsgáljuk, a paletta az egyszerü izomgörcstől (pl. lábikragörcs) a komplex, célirányos mozgás-megnyilvánulásokig tart. Jelentkezhetnek repetitív mioklónusok, disztoniform túlmozgások, komplex mozgások (pl. járkálás, autóvezetés, szexuális jellegü mozgások), akár heves pszichés (pánik) és vegetatív (szapora szívverés és emelkedett légzésszám) reakciók kíséretében.

A mozgásjelenségek legtöbb típusa a gyermekkorban gyakori úgynevezett paraszomniák csoportjába tartozik. Bár számtalan jellegzetes képviselöje van, a nagyságrend eltörpül az alvásfüggő légzészavarokban (pl. obstruktív alvási apnoe betegség) és az alvásfüggő mozgászavarokban (nyugtalan láb szindróma és periodikus végtagmozgászavar betegség) szenvedő betegek számához képest. Szintén nem lehet figyelmen kívül hagyni az alvás során jelentkező epilepsziák jelentőségét sem. Differenciál-diagnosztikai szempontból fontos végiggondolni 
az inszomniák, illetve egyes belgyógyászati kórképek kapcsolatát is. A legfontosabb alvásfüggő mozgászavarokat a II. táblázat mutatja [4]. Az alvás nemcsak mozgásformákat tud kiváltani, hanem bizonyos mozgásformák megszünését is eredményezi. Jól ismert példa, hogy a hiperkinetikus mozgászavarok jelentős része $a z$ alvás alatt jelentősen javul vagy akár teljes egészében meg is szűnhet. Nemcsak az éjszakai alvás, hanem a pár órás nappali pihenés alatt is jól megfigyelhetö, hogy a Parkinson-kór nyugalmi tremora, vagy a disztóniások fázisos hiperkinezisei is jelentős mértékben javulhatnak.

Ez a jelenség azért is érdekes, mert éjszaka - a dopaminerg gyógyszerelés hatásának oldódásával párhuzamosan - a rigiditás és a vele járó izomgörcsök általában fokozódnak, ami a beteg felébredéséhez is vezethet. Ennek ellenére a betegek és a hozzátartozóik elmondása alapján nem a hiperkinetikus tünetek (pl. tremor), hanem a hipokinezis fokozódásával járó problémák (rigiditás, disztónia) jelentenek panaszt.

Hipokinetikus állapotok alvás alatt nemcsak neurodegeneratív megbetegedések esetében jelentkezhetnek. Hipnotikumok, illetve alkohol esetében a normális alvás alatti mozgásmintázat is lecsökkenhet. Jól ismert példa a n. radiális nyomásos sérülése („vasárnap reggeli bénulás”), melynek oka abban kereshető, hogy a tartós végtagkompresszió nem indukál testhelyzet változtatást.

\section{Paraszomniák}

A paraszomniák az ébredés, a parciális ébredés és az alvás-ébrenlét átmenet betegségei, melyeket autonóm idegrendszeri és vázizomzat aktiválódás jelei kísérnek [4].
A legváltozatosabb kórképek, mozgási és magatartási megnyilvánulások ebbe a csoportba tartoznak. Számtalanszor már gyermekkorban találkozunk velük, néhány képviselöje inkább a felnőttkorra jellemző.

A paraszomniák osztályozása alapvetően azon alapul, hogy köthetö-e valamely alvásfázishoz, vagy sem. Ennek alapján a mozgás-megnyilvánulás jelentkezhet lassú hullámú alvásban, REM alvásban, illetve az események egy része nem köthető szorosan alvásfázishoz [4].

Amennyiben csak a mozgás-megnyilvánulások jellegzetességeit tekintjük át, látható, hogy az elemi mozgásoktól kezdve összetett mozgásmintázatok is megjelenhetnek. Az időzítés, mint fontos differenciál-diagnosztikai információ nélkül nehéz eldönteni az eredetüket.

A fontosabb megjelenési formák a következők:

- mioklónusok,

- ritmikus mozgások,

- disztoniform mozgások,

- komplex cselekvéssorok, esetleg vokalizációval,

- pánikroham szerü vegetatív kísérő tünetek.

$\mathrm{Az}$ alvásszerkezet megfelelő ismerete fontos ezen kórképek diagnosztikájához. A lassú hullámú alváshoz kötődő események (az úgynevezett ébredési zavarok, pl. alvajárás, alvás alatti beszéd, zavart ébredés, stb.) az első mélyalvás ciklusban jelentkeznek legnagyobb valószínüséggel. Ez azt jelenti, hogy az elalvás utáni első 2-3 órában láthatjuk, várhatjuk. A REM fázishoz kapcsolódó jelenségek (pl. REM magatartászavar, nightmare) pedig az alvás második felében várhatók. A kikérdezés során mindig fontos kitérni az időzítésre, vagyis az alvás so- 
II. táblázat. Alvás alatti epizódikus motoros események felosztása

(AASM, 2014) és gyakorisága

\begin{tabular}{|c|c|}
\hline Motoros esemény & Gyakoriság (felnőttkori) \\
\hline \multicolumn{2}{|l|}{ Parasomniák } \\
\hline $\begin{array}{l}\text { - NonREM } \\
\text { Zavart ébredés } \\
\text { Night terror } \\
\text { Alvajárás } \\
\end{array}$ & $\begin{array}{r}2,9-4,2 \% \\
2,2 \\
1-4 \%\end{array}$ \\
\hline $\begin{array}{l}\text { - REM } \\
\text { Nightmere } \\
\text { Alvási paralízis } \\
\text { REM magatartászavar }\end{array}$ & $\begin{array}{r}2-8 \% \\
6,2 \% \\
2 \% \\
\end{array}$ \\
\hline \multicolumn{2}{|l|}{ Alvásfüggő mozgászavarok } \\
\hline $\begin{array}{l}\text { - PLMD (periodikus végtag-mozgászavar) } \\
\text { - Bruxizmus } \\
\text { - Éjszakai lábikragörcs } \\
\text { - Jaktáció }\end{array}$ & $\begin{array}{r}3-5 \% \\
8-31 \% \\
50-60 \% \\
\text { nincs adat }\end{array}$ \\
\hline \multicolumn{2}{|l|}{ Egyéb } \\
\hline $\begin{array}{l}\text { - Elalvási mioklónusok } \\
\text { - Alvás alatti beszéd } \\
\text { - Benignus mioklónusok } \\
\text { - Pszichogén nem epilepsziás rosszullét } \\
\text { - Éjszakai pánikzavar } \\
\text { - Alvásfüggő légzészavarok } \\
\text { - GERD } \\
\text { - Narkolepszia } \\
\text { - Enuresis nocturna } \\
\text { - Mioklónusok } \\
\text { - Excesssiv fragmentált mioklónus } \\
\text { - Propriospinalis mioklónus } \\
\text { - Ritmikus mozgászavarok (elalvás során) } \\
\text { - Akatízia }\end{array}$ & $\begin{array}{r}70 \% \\
4 \% \\
\text { nincs adat } \\
0,00002-0,00033 \% \\
\\
2-5 \% \\
8-21 \% \\
0,03-0,05 \% \\
0,5 \% \\
\text { nincs adat } \\
\text { nincs adat } \\
\text { nincs adat } \\
6,3 \% \\
\text { (schizophreniában) }\end{array}$ \\
\hline
\end{tabular}

rán (pontosabban az elalvástól számítva) mikor jelenik meg az oda nem illő mozgástöbblet.

A panaszok kialakulásában nagy szerepe van az úgynevezett disszociációs jelenségeknek, állapotnak („status dissociatus"). Egyes elképzelések szerint az alapját a különböző agyi régiók eltérő „alvási-ébrenléti állapota” okozza, melynek során megjelennek alvásra jellemző, illetve ébrenlétre jellemző események is. Ilyen például az alvajárás (szomnambulizmus során delta hullámú mélyalvásban kialakuló éber állapotra jellemző mozgás megnyilvánulás, vagy a REM magatartászavarban kialakuló motoros esemény, REM fázisban) [5].

\section{Ébredési paraszomniák}

A leggyakoribb típusok, mint pl. az alvajárás ebbe csoportba tartoznak $[6,7]$. Főbb képviselői még a zavart ébredés, il- 
letve az úgynevezett sleep terror (pavor nocturnus). Ezek közös jellemzöit a III. táblázat tartalmazza.

Az alvajárás a legismertebb képviselö. Az egyszerű felüléstől a komplex cselekvéssorokig mindenféle jelenséget leírtak.

Ritkábban fordul elő az éjszakai félelmetes felrettenés, jelentkezhet gyermek és felnőttkorban is. Ennek során az alvó felsikolt. Mindenki összefut, megijed. Az érintett minden nehézség nélkül visszaalszik, s másnap nem emlékszik semmire a történtekből. A felnőttkori formájában pszichés tényezők is szerepet játszhatnak a kialakulásban.

$\mathrm{Az}$ éjszakai zavart felébredés gyakran előfordul felnőtteken is. Az alvó - illetve helyesebben az ébredő - egy ideig nem tudja, hogy hol van, mi történt. Nem megfelelően viszonyul környezetéhez, alvótársához, sőt akár sérüléseket okozhat.

Fontos tudni, hogy egy lassú hullámú alváshoz kötött mozgásjelenség megléte nem zárja ki, hogy az adott páciensnél másik, ugyan ebbe a csoportba sorolható betegség is kialakuljon, sőt általában kombinálódnak, éjszakáról éjszakára változhatnak.

\section{REM fázishoz kapcsolódó paraszomniák}

Közös jellemzőjük, hogy többnyire felnőttkorban jelentkeznek, egyes képviselöi inkább az idősebb korosztályban fordulnak elő [8]. Ahogy az ébredési paraszomniáknál, ebben a betegségcsoportban is disszociációs jelenségek alakulnak ki, a REM-re jellemző motoros, vegetatív és magatartási események együttállása megszűnik.

A legfontosabb kórkép ebben a csoportban a REM magatartászavar $[8,9]$. A REM fázisra jellemző motoros gátlás felfüggesztödik, ennek következtében megjelenítjük az álmainkat. Ilyenkor az
III. táblázat. Az ébredési paraszomniák közös jellemző $i$

- A jelenség mindig lassú hullámú alvásban jelentkezik, általában az alvás első harmadában és éjszakánként csak egy (esetleg kettő) alkalommal.

- Az alvót ilyenkor nehéz felébreszteni, „felébredve" zavartság észlelhető.

- A páciens nem emlékszik a történtekre.

- Külső ingerekre adott reakciója csökkent.

- Gyakoribb gyermekkorban, felnőttkorra az esetek döntő többségében kinövik a panaszokat.

- Az alvó magatartási szinten mozgásokat, komplex mozgássorokat produkál, lassú hullámú alvás EEG jellemgzetességei mellett.

alvótárs futó, verekedő, stb. mintázatokat lát, $s$ páciens felébredve elmondja, hogy álmában kergették, harcolt, stb. A REM magatartászavar legfőbb veszélye a sérülések kialakulása, amely mind a pácienset, mind az alvótársat érintheti. Fontos ennek a kórképnek az ismerete abból a szempontból is, hogy bizonyos degeneratív neurológiai kórképek (pl. Parkinson betegség, multiszisztémás atrófia) vonatkozásában a preklinikai fázis egyik tünete lehet [10].

REM magatartászavarra jellemző eseménysor jelentkezhet narkolepsziában is. Amíg a narkolepsziában ez a magatartásminta csak ritkán, éjszakánként általában egy alkalommal fordul elö, addig a REM magatartászavar betegségben éjszakánként többször is megfigyelhető [11].

Alvási paralízis önálló betegségként is előfordul, de narkolepsziának is lehet kísérő tünete. A lidérces álom (nightmare) hasonlít a lassúhullámú alvásban jelentkező felrettenéshez. A leglényegesebb különbségek, hogy a páciens nem, vagy nehezen alszik vissza a felrettenés után, valamint inkább felnőtteket érint, visszaemlékszik a történtekre és gyakran fellelhető egy háttérben kiváltó pszichopatológia. 


\section{Egyéb paraszomniák}

Legfőbb jellegzetességük, hogy nem lehet az előző kategóriákba (ébredési és REM függő jelenségek) beilleszteni.

A számos képviselő közül csak a bruxizmust szeretnénk kiemelni, amely jó példája annak, hogy - ellentétben az előzőekkel - nem kell mindig nagy, tömeges mozgás ahhoz, hogy az alvásszerkezetet megváltoztassa, az alvást a gyakori mikroébredéseken keresztül felületessé tegye [12].

\section{Ébrenlét-alvás határán kialakuló mozgásjelenségek}

Ezeket a jelenségeket korábban a paraszomniák csoportjába sorolták. Közös jellemzöjük, hogy közvetlenül az elalvás elötti időszakban jelentkeznek, megnehezítve azt, de alapvetöen benignus megnyilvánulások. Ezzel elalvási inszomnia képét utánozhatják. A leggyakoribb jelenség az elalvási mioklónus. Ennek kapcsán hirtelen, villanásszerű, kezekre, lábakra lokalizálódó megrándulás alakul ki, mely az éppen szendergésből visszaébreszti az aludni vágyót. Jelentősége föleg differenciál-diagnosztikai szempontból van, gyakoriak újszülött és csecsemőkorban is, epilepszia látszatát kelthetik. Fontos még a ritmikus mozgászavarok (fejmozgások, törzsmozgások), illetve a propriospinális mioklónusok (a fekvő helyzetben megjelenő flexiós jellegü repetitív mozgások) ismerete.

\section{Alváshoz, vagy felébredéshez kapcsolható epilepsziák}

(IV. táblázat)

Benignus centrotemporális epilepsziára jellemzőek az éjszakai faciobrachiális motoros rohamok, amelyek néha másodlagosan grand mal rohamokba men- nek át. A szindróma gyermekeket, fiatal serdülöket érint, és felnőttkorra megszünik. Szinte bármely antiepileptikum megszünteti a rohamokat (használhatunk carbamazepint, oxcarbazepint vagy lamotrigint) [13].

A frontális lebeny epilepsziák közül a szupplemeter motoros areából induló tónusos rohamok gyakran éjjelente jelennek meg. A nokturnális frontális lebeny epilepsziára (NFLE) jellemzők az éjszakai hipermotoros rohamok, sokszor disztoniform elemekkel, vokalizációval. A betegség rendszerint fiatalkorban és serdülőkorban kezdődik (10-20. életév között), szemben az SWS paraszomniákkal, amelyek rendszerint fiatalabb életkorban, és a REM magatartás-zavarral, amely viszont idősebb korra jellemző [14]. 25\%-ban mutat familiaritást, de a pontos genetikai mechanizmust csak néhány esetben ismerjük: a nikotinerg acetilkolin receptorokat kódoló gén mutációját lehetett kimutatni. A betegséget tehát feltehetőleg különböző mutációk okozhatják, hiszen még a nikotinerg receptor-diszfunkcióban is legalább háromféle független mutáció létezik [15]. Az NFLE csak $70 \%$-ban reagál antiepileptikumra (fóleg carbamazepinre), ezért pusztán a gyógyszer-rezisztencia nem különíti el

IV. táblázat. Alvással, vagy ébredéssel kapcsolatos epilepsziák

- Benignus centrotemporális gyermekkori epilepszia

- Frontális lebeny epilepszia

- Szupplementer szenzomotoros

- Nocturnális frontális lebeny epilepszia

- Lennox-Gastaut szindróma

- Folyamatos „spike and wave” epilepszia alvásban (CSWS)

- Juvenilis mioklónusos epilepszia

- Absence epilepszia

- Ébredési GM 
a paraszomniáktól. Mivel mind alvajárásra, mind NFLE-re jellemző a családi halmozódás, ezért ez a szempont sem igazán perdöntő a differenciál-diagnosztikában (melyet máshol részletezünk). Még nagyobb differenciál-diagnosztikai problémát jelezhet az, hogy gyakori az NFLE és a paraszomniák együttes elöfordulása akár egy családon vagy egyénen belül [16].

A juvenilis mioklónusos epilepsziára (JME) reggeli (ébredés utáni) mioklónusok és grand malok jellemzőek. Ritkábban absence rohamok is elöfordulhatnak. Ez a leggyakoribb, felnőtt korban is fennálló epilepszia-forma, a teljes népesség 0,1\%-át érinti. A rohamok és mioklónusok alvásmegvonásra fokozódnak, illetve jelennek meg. Első választandó gyógyszere a valproát, amely az esetek 80-90\%-ban megszünteti a rohamokat (de levetiracetam, lamotrigin is választható). Fontos tudni, hogy a gyógyszerelést ebben a kórképben soha nem szabad abbahagyni!

A JME „idiopátiás” formakörbe tartozó epilepszia, ami azt jelenti, hogy feltehetőleg genetikai alapú a fokozott görcskészség, a családi halmozódáson kívül nincs más etiológia. Szintén idiopátiás epilepszia az ébredési GM epilepszia és az absence epilepszia. Ez utóbbi rendszerint iskoláskorban kezdődik, első választandó gyógyszere az ethosuxmid, és az esetek zömében (több mint 70\%-ában) serdülőkorra elmúlik. Jellemző rá, hogy az éberségi szint csökkenése provokálja a rohamokat [17].

\section{Mozgászavarok mellett jelentkező alvási problémák}

A legtöbb mozgászavar megjelenése a bazális ganglionok megváltozott, patológiás müködészavarával magyarázha- tó. Főemlősvizsgálatok alapján tudjuk, hogy a dopamin rendszer müködését a circadián ritmus is befolyásolja.

Az utóbbi 10 évben kezdett a klinikai kutatás a Parkinson-kór nem-motoros tünetei felé fordulni [10]. Egy 2003-as tanulmánynak köszönhetően ma már tudjuk, hogy a betegek életminőségét a nem-motoros tünetek jelenléte legalább annyira befolyásolja, mint a klasszikus motoros tünetek (tremor, rigor, bradikinezia) hatása. A Parkinson-betegek közel háromnegyedében a depressszió mellett az alvászavar jelenti a legtöbb gondot okozó nem-motoros tünetet.

Érdekes klinikai megfigyelés, hogy az alvás során (már a felületes stádiumokban is) a remegés jelentősen javul vagy akár teljesen meg is szünhet. Ezzel szemben az izommerevség csak átmenetileg javul. Feltehetőleg az antiparkinzon gyógyszerelés folyamatos kiürülésével párhuzamosan, 3-4 órával az elalvást követően az újra kifejezetté váló rigiditás miatt a beteg már fájdalmas izomgörcsökre ébredhet fel. Típusosan a reggeli felébredéskor a rigiditás mellett OFF disztónia is megjelenhet, ami a beteg fájdalmait tovább fokozza.

Egyéb mozgászavarokban, úgymint disztóniában és choreában, a túlmozgások általában alvás alatt megszünnek. Ennek oka szintén ismeretlen.

\section{A kivizsgálás legfontosabb lehetőségei, elemei}

\section{Az anamnézis-felvétel szempontjai}

$\mathrm{Az}$ alvásfüggő mozgászavarok legfőbb diagnosztikai nehézségét pontosan a megjelenés körülményei (alvás alatt történik, nincs mindig szemtanú, a páciens csak ritkán emlékszik vissza a történtekre) adják. Emiatt különös gondosságot, 
speciális stratégiát igényel az alvással kapcsolatba hozható mozgásformák kivizsgálása [18]. A legfontosabb kérdések az V. táblázat tartalmazza.

Amennyiben ezeket végiggondoljuk, az esetek többségében eldönthetö, hogy milyen mozgástöbbletről van szó. A mai technikai fejlettség mellett szinte minden háztartásban jelenlevő videokamera vagy mobiltelefon használatával megkérhetjük az alvótársat, hogy készítsen felvételt az eseményekről. Alvásnapló segítségével (melyet a páciens tölt akár hetekig) feltérképezzük az alvási szokásokat, amely segítségünkre lehet a panaszok eredetének megítélésében.

\section{Epilepszia versus paraszomnia: az elkülönítés alapvető megfontolásai} $\mathrm{Az}$ elkülönítésben a legfontosabb a mozgásjelenségek sztereotip, vagy variábilis lezajlásának megítélése, időzítésének és ismétlódésének az ismerete [19]. Ezen három alapvető jellemző ismeretében az esetek jórészében nagy biztonsággal megítélhetö az eredet. A differenciál-diagnosztikához fontos információt szolgáltathatnak a hozzátartozók, de a video-EEG monitorozás és a poliszomnográfiás vizs- gálat egyértelmü bizonyítékot szolgáltathat a mögöttes patológia megítélésében is [20].

A REM magatartászavart a temporális lebeny epilepsziában jelentkező komplex parciális (pszichomotoros) rohamtól, az alvajárást sokszor a temporális roham posztiktális zavartságától kell elkülöníteni. De még ennél is nagyobb kihívás a nokturnális frontális lebeny epilepszia (NFLE) és a többi paraszomnia elkülönítése. Ez a típusú epilepszia éjszakai hipermotoros rohamokkal jár, elsősorban az éjszakai félelmes felrettenéstől kell elkülöníteni.

Epileptiform eredet mellett szól a sztereotip, szinte mindig ugyanolyan módon zajló motoros mintázat. Gyakran a motoros megnyilvánulás disztoniform, ballisztikus elemeket tartalmaz (pl. nocturnális frontális lebeny epilepsziában). Paraszomniák variábilisabban jelentkeznek, alkalomról alkalomra más mozgás-megnyilvánulásokat láthatunk akár a szomnambulizmus, akár REM magatartászavar esetén. Amíg a legtöbb paraszomnia éjszakánként többnyire egy alkalommal jelentkezik, addig az alvásfüggő epilepsziák többször is ismétlődhetnek az alvás során.

\section{V. táblázat. Az anamnézisfelvétel szempontjai}

- A páciens és a hozzátartozók kikérdezése:a születés körülménye (koraszülés, érettség, esetleges lázgörcs), gyermekkori betegségtörténet (furcsa mozgások - pl. alvajárás megléte) felderítése.

- A páciens visszaemlékszik-e a történtekre, és hogyan, illetve ilyenkor emlékszik-e álmokra.

- Milyen rendszerességgel (hetente, havonta hányszor jelentkezik a furcsa viselkedés).

- Egy éjszaka hányszor figyelnek meg eseményt és hogyan jellemzik azt.

- A mozgásesemény az éjszaka melyik részében jelentkezik, azaz milyen az időzítése?

- A rosszullét, vagy a furcsa mozgás mindig ugyanúgy zajlik (sztereotip) vagy pedig változékony.

- Vannak-e egyéb kísérőjelenségek (izzadás, nyáladzás, inkontinencia, horkolás, légzéskihagyás)?

- Kialakulnak-e sérülések, és milyen súlyosságúak?

- Ki lehet-e deríteni olyan tényezőt, amely provokálja, elősegíti az események megjelenését (pl. alvásmegvonás, alkoholfogyasztás)?

- Jelentkezett-e hasonló esemény a család több tagjában, vagy esetleg a szülőkben?

- Alvási szokások (pl. ágyban töltött idő, alvásidő, felébredések, az alvás időzítése, többműszakos munkakör, stb.).

- Társbetegségek. 
$\mathrm{Az}$ epileptogén eredetü események időzítése nem olyan körülírt, mint a paraszomniáké, az éjszaka során bármikor megjelenhetnek. A paraszomniák esetén a az alvajárás konzekvensen az alvás első harmadában, míg a REM magatartászavar az hajnali időszakban jelenik meg legnagyobb valószínüséggel.

A legfontosabb szempontokat és jellemzőket az VI. táblázat tartalmazza. $\mathrm{Az}$ események pontos megfigyelésében, megítélésében nagy jelentősége van az akár több napos videóEEG vizsgálatnak [21]. Mindazonáltal, még a videó-EEG specificitása és szenzitivitása sem 100\%os a differenciál-diagnózisban [19].

\section{A frontális lebeny epilepszia- paraszomnia skála (FLEP) szerepe a differenciál-diagnosztikában.}

A paraszomnia-epilepszia differenciáldiagnosztika nem áll meg a fenti lehetőségeknél. Speciális, a jellegzetességei alapján (motoros mintázat jellege és az EEG pozitivitás hiánya) legnagyobb kihívást a nokturnális frontális lebeny epilepszia (NFLE) és az ébredési paraszomniák elkülönítése jelenti. Annak ellenére a patofiziológiájukban számos közös vonás, összefüggés található (pl.: frontális kolinergiás ébresztő mechanizmusok, funkciók, feltételezhető genetikai háttér) [5], a differenciálást számos különbség teszi lehetővé. Az NFLE 25-44\%-ában negatív az iktális EEG, az esemény rövid, hiányzik a posztiktális lassulás. A probléma ráadásul az, hogy iktális EEG-hez csak éjszakai videó-EEG-vel juthatunk, ami nemcsak költséges, hanem nehezen hozzáférhető eljárás. A „rutin” EEG során ugyanis itt nem jelenik meg epilepsziára jellemző potenciál. Ezek hiányában a korábban ismertetett három alapvető jellemző (időzítés, ismétlődés, variábilitás) mellett számos egyéb jellemző segítheti a valószínűségi differenciálást. Ennek az eszköze az úgynevezett FLEP (frontális lebeny epilepszia és paraszomnia) skála [16]. A fentiek mellett figyelembe veszi a panaszok életkori kezdetét, tartamát, a visszaemlékezést az eseményre, valamint a vokalizáció jelenségét. A kérdésekre adott válaszok pontszáma alapján alakul ki a FLEP skála pontértéke. A vizsgálatok alapján megfelelő specificitással és szenzitivitással képes elkülöníteni az egyes paraszomniákat a NFLE-től. A FLEP skálát az VII. táblázat mutatja.

Ugyan a FLEP skála nem tartalmaz rá vonatkozó kérdéseket, de a differenciálásban segítséget nyújthatnak a következő megfigyelések is:

Ébredési paraszomniáknál az esetek közel felében provokáló faktorként azonosítható külső környezeti inger (zaj), vagy a szervezeten belülről jövő esemény (köhögés, horkolás), az NFLE esetén ilyen csak az esetek kevesebb, mint

VI. táblázat. Paraszomniák, alvás során jelentkezö epilepsziák és pszichogén események elkülönitése a klinikum alapján

\begin{tabular}{|l|l|l|l|l|}
\hline & $\begin{array}{l}\text { NREM } \\
\text { Paraszomnia }\end{array}$ & $\begin{array}{l}\text { REM } \\
\text { Paraszomnia }\end{array}$ & Epilepszia & $\begin{array}{l}\text { Psichogen. } \\
\text { mozgászavar }\end{array}$ \\
\hline Időzítés: & első harmad & $\begin{array}{l}\text { az alvás utolsó } \\
\text { harmadában }\end{array}$ & bármikor & bármikor \\
\hline Visszaemlékezés: & ált. nincs & van & ált. nincs & lehet \\
\hline Sztereotíp mozgások & nincs & nincs & lehet & nincs \\
\hline „Rosszullétek” száma / éj: & általában $1 \times$ & általában $1 \times$ & töbször & változatos \\
\hline
\end{tabular}


VII. táblázat. FLEP (Frontal Lobe Epilepsy Parasomnia) skála

\begin{tabular}{|c|c|c|}
\hline Klinikai jellemző & & cám \\
\hline $\begin{array}{l}\text { Kezdet: } \\
\text { Milyen életkorban jelentkeztek az első tünetek? }\end{array}$ & $\begin{array}{l}55 \text { év alatt } \\
55 \text { év felett }\end{array}$ & $\begin{array}{r}0 \\
-1\end{array}$ \\
\hline $\begin{array}{l}\text { Tartam: } \\
\text { Mennyi ideig tart egy tipikus rosszullét? }\end{array}$ & $\begin{array}{l}2 \text { perc alatt } \\
2-10 \text { perc } \\
10 \text { perc felett }\end{array}$ & $\begin{array}{r}+1 \\
0 \\
-2\end{array}$ \\
\hline $\begin{array}{l}\text { Események száma: } \\
\text { Hányszor jelentkezik a rosszullét egy éjszaka? }\end{array}$ & $\begin{array}{l}1-2 \\
3-5 \\
5 \text {-nél több }\end{array}$ & $\begin{array}{r}0 \\
+1 \\
+2\end{array}$ \\
\hline $\begin{array}{l}\text { Időzítés: } \\
\text { Az éjszaka melyik részében jelentkeznek a rohamok? }\end{array}$ & $\begin{array}{l}30 \text { percen belül (elalvástól) } \\
\text { Más időzítéssel }\end{array}$ & +1 \\
\hline $\begin{array}{l}\text { Tünetek: } \\
\text { Jelentkezik-e aura? }\end{array}$ & $\begin{array}{l}\text { Igern } \\
\text { Nem }\end{array}$ & $\begin{array}{r}+2 \\
0\end{array}$ \\
\hline Vándorol-e hálószobán kívülre a páciens az esemény során? & $\begin{array}{l}\text { Igen } \\
\text { Nem (vagy bizonytalan) }\end{array}$ & $\begin{array}{r}-2 \\
0\end{array}$ \\
\hline $\begin{array}{l}\text { Komplex, célszerű magatartás a rohamok során? } \\
\text { (pl. tárgyak felvétele, öltözködés) }\end{array}$ & $\begin{array}{l}\text { Igen } \\
\text { Nem (vagy bizonytalan) }\end{array}$ & $\begin{array}{r}-2 \\
0\end{array}$ \\
\hline $\begin{array}{l}\text { Szerepel-e disztoniform tartás az anamnézisben? } \\
\text { (pl. tónusos végtagextenzió, görcs) }\end{array}$ & $\begin{array}{l}\text { Igen } \\
\text { Nem (vagy bizonytalan) }\end{array}$ & $\begin{array}{r}+1 \\
0\end{array}$ \\
\hline $\begin{array}{l}\text { Sztereotipicitás: } \\
\text { Az események nagyfokban sztereotípek, vagy variábilisak? }\end{array}$ & $\begin{array}{l}\text { Nagyfokban } \\
\text { Kissé variábilis } \\
\text { Nagyon variábilis }\end{array}$ & $\begin{array}{r}+1 \\
0 \\
-1\end{array}$ \\
\hline $\begin{array}{l}\text { Emléknyom: } \\
\text { Emlékszik a páciens a rosszullétre? }\end{array}$ & $\begin{array}{l}\text { Igen } \\
\text { Nem }\end{array}$ & $\begin{array}{r}+1 \\
0\end{array}$ \\
\hline $\begin{array}{l}\text { Vokalizáció: } \\
\text { Beszél-e a páciens az esemény alatt? } \\
\text { Ha igen, visszaemlékezik-e rá? }\end{array}$ & $\begin{array}{l}\text { Nem } \\
\text { Igen (hangok, egy szó) } \\
\text { Igen (összefüggő, részleges } \\
\text { vagy hiányzó visszaemlékezés) } \\
\text { Igen (összefüggő visszaemlé- } \\
\text { kezéssel) }\end{array}$ & $\begin{array}{r}0 \\
0 \\
-2 \\
\\
+2\end{array}$ \\
\hline
\end{tabular}

Forrás: Arch Neurol. 2006;63(5):705-709. 
10\%-ában volt kimutatható. Míg az NFLE esetén az események közel 90\%ban felébrednek a páciensek a rosszullétet követően, ébredési paraszomniák nál ez csak az esetek $25 \%$-ában mutatható ki, jellemzőbb a lassú hullámú alvás folytonosságának a fennmaradása [5].

\section{A kivizsgálás lehetőségei: poliszomnográfia, videó-EEG}

Amennyiben az anamnesztikus adatok, a roham leírása, az alvótárs beszámolója nem elég az éjszakai mozgástöbblet megítéléséhez, a vizsgálatokat videóEEG-vel, vagy videómegfigyeléssel egybekötött poliszomnográfiával egészíthetjük ki. Ez utóbbi során egy éjszaka rögzítjük az agyi elektromos jeleket (EEG), szemmozgást, izomtónust, horkolás hangját, légáramlást, hasi és mellkasi légzőmozgásokat, testhelyzetet, a vér oxigénszintjét, pulzust, EKG-t és végtagmozgásokat.

Amennyiben a vizsgált éjszakán észlelünk eseményt, megfigyelhetjük a jellegzetességeit, időzítését, ismétlődését, és esetlegesen a provokáló, mikroébredéseket okozó faktorokat (pl. repetitív apnoe, végtagmozgások stb.).

Poliszomnográfiás vizsgálat az Amerikai Alvásmedicína Akadémia (AASM) [22] szerint a következő esetekben ajánlott:

- A mozgástöbblet atípusos a megjelenési időben, magatartásmintázatában, azaz a megjelenési forma és az időzítés között ellentmondás áll fenn. Ilyen lehet például álomtevékenységhez tartozó magatartásmintázat, amely nem az alvás REM dominanciát mutató utolsó harmadában jelentkezik.

- Szokatlan életkori kezdet: pl. A leírás alapján egyértelmüen bizonyos paraszomniának besorolható moz- gástöbblet nem a betegségre jellemző életkorban kezdődik, megbízható anamnesztikus adatok alapján gyermekkorban még nem volt jelen.

- Sérülések kockázata nagy. Ilyenkor gyors és megfelelő terápiás stratégia kialakítása miatt szükséges a pontos diagnosztika.

- Sztereotip, repetitív eseményeket figyelnek meg: ekkor az epileptogén eredet valószínűsége nagy.

- Szokatlan gyakorisággal jelentkeznek az események.

- Kifejezett másnapi aluszékonyság, vagy inszomnia kíséri a panaszokat. Ezek a kísérőjelenségek esetleges egyéb primer alvászavar (alvásfüggő légzészavar, alvásfüggő mozgászavar) mikroébredéseket okozó szerepére hívják fel a figyelmet.

- Alvási apnoe betegségre, nyugtalan láb szindrómára utaló egyértelmű panaszai vannak a páciensnek, amelyek - mint korábban láttuk - a patológiás mikroébredés rendszeren keresztül indukálhatnak egyéb mozgászavarokat.

Az epilepszia kivizsgálás során alkalmazott hosszú távú videó-EEG monitorozás megfelelö, kiterjesztett elektródakészlet alkalmazásával felhívhatja a figyelmet egyes alvászavarok meglétére. Kiegészítésként javasolt alap kardiorespiratórikus paraméterek regisztrálása. Ilyenek lehetnek például az pulzoximéter, a nazális légáramlás, valamint a mellkasi légzési aktivitás megfigyelése.

Amennyiben a vizsgálat során felmerül alvászavarral való összefüggés, lehetöség van kiterjesztett, több kardiorespiratórikus és egyéb paramétert (pl. végtagi izom EMG) is tartalmazó poliszomnográfiás vizsgálat kivitelezésére alváslaboratóriumi körülmények között. 
Természetesen az irány visszafelé is igaz. Alvásfüggő mozgászavarok vizsgálata során video regisztrálással egybekötött poliszomnográfiás vizsgálat javasolt. Természetesen ilyenkor nem elég az alvás makro és mikrostruktúrájának leírásához rutinban használt frontális, centrális és occipitális EEG csatornák használata, hanem szükséges a minimum 21 csatornás EEG regisztrálás (egyes poliszomnográfok esetében akár 32, vagy több EEG csatorna is rendelkezésre áll). Pozitív esetben további, hoszszú távú monitorozásra javasolt epilepszia monitorozó egységbe való irányítás.

E tények, jelenségek miatt fontos az alapos, minden körülményre kiterjedő, megfelelő anamnézisre, szülők, hozzátartozók kikérdezésére, szükséges esetben alvásvizsgálatra alapozott diagnózis. Ebben nyújthatnak segítséget alvásmedicínában jártas szakemberek és az alváslaboratóriumi hálózat.

\section{Irodalom}

[1] Faludi B., Bone B., Komoly S., Janszky J.: $\mathrm{Az}$ alvásfüggő légzészavarok és epilepszia: kapcsolódási pontok és terápiás megfontolások. Ideggyógyászati szemle/ Clinical Neuroscience, 2015, 68 (11-12): 374-382.

DOI: $10.18071 /$ isz.68.374

[2] Faludi B.: Paraszomniák. In: Szakács Z., Köves P. (szerk.): Az alvásmedicina kézikönyve. Budapest, Spring. Med. Kiadó, 2017, 378389.

[3] Faludi B., Kovács N., Janszky J., Komoly S.: Alvás alatti kóros mozgásjelenségek és azok differenciáldiagnosztikája: update 2013. Ideggyógyászati szemle/Clinical Neuroscience, 2015, 68 (5-6): 165-177.

DOI: $10.18071 /$ isz.68.0165

[4] American Academy of Sleep Medicine: International classification of sleep disorders: diagnostic and coding manual. 3nd edition. American Academy of Sleep Medicine, Darien, IL., 2014.
[5] Halász P, Kelemen A. and Szűcs A: Physiopathogenetic interrelationship between nocturnal frontal lobe epilepsi and NREM arousal parasomnias. Epilepsy Research and Treatment, 2012, ID 312693.

DOI: $10.1155 / 2012 / 312693$

[6] Hughes, J.R.: A review of sleepwalking (somnambulism): the enigma of neurophysiology and polysomnography with differential diagnosis of complex partial seizures. Epilepsy Behav., 2007, 11: 483-91.

DOI. 10.1016/j.yebeh.2007.08.013

[7] Plazzi, G. et al: Sleepwalking and other ambulatory behaviours during sleep. Neurol. Sci., 2005, 26 Suppl., 3: 93-8.

DOI: $10.1007 /$ s10072-005-0486-6

[8] Mahowald, M.W., Schenck, C.H.: REM sleep parasomnias. In: Kryger, M.H., Roth, T., Dement, W.C. ed. Principles and Practice of Sleep Medicine. 4th ed. Philapdelphia, PA: Elsevier Saunders, 2005, 897-916.

[9] Faludi B.: Paraszomniák mozgásmegnyilvánulásai. Háziorvos továbbképző szemle, 2003, 5: 398-400.

[10] Iranzo, A.: Sleep-wake changes in the premotor stage of Parkinson disease. J. Neurol. Sci., 2011, 310: 283-5.

DOI: $10.1016 /$ j.jns.2011.07.049

[11] Cipolli, C., Franceschini, C., Mattarozzi, $\mathrm{K}$, et al: Overnight distribution and motor characteristics of REM sleep behaviour disorder episodes in patients with narcolepsycataplexy. Sleep Med., 2011, 12: 635-40.

DOI: 10.1016/j.sleep.2010.12.016

[12] Huynh, N., Kato T, Rompré, P.H., et al.: Sleep bruxism is associated to micro-arousals and an increase in cardiac sympathetic activity. J. Sleep Res., 2006, 15: 339-46.

DOI: 10.1111/j.1365-2869.2006.00536.x

[13] Janszky J., Gyimesi Cs., Bóné B. et al.: Alvás és Epilepszia. In: Szakács Zoltán, Köves Péter (szerk.) Az alvásmedicina kézikönyve. 503 o. Budapest: Spring. Med. Kiadó, 2017, 329342.

[14] Tinuper, P., Bisulli, F., Provini, F.: The parasomnias: Mechanism and treatment. Epilepsia, 2012, 53 (Suppl 7): 12-19.

DOI: 10.1111/j.1528-1167.2012.03710.x 
[15] Ferini-Strambi L., Sansoni, L., Combi, R.: Nocturnal frontal lobe epilepsy and the acethylcholine receptor. Neurologist, 2012, 18: 343-349.

DOI: 10.1097/NRL.0b013e31826a99b8

[16] Derry, C.: Nocturnal frontal lobe epilepsy vs parasomnias. Current Treatment Options in Neurology, 2012,14: 451-463.

DOI: $10.1007 / \mathrm{s} 11940-012-0191-8$

[17] Janszky J., Horváth R., Bóné B. et al.: Epilepszia és epilepsziás rohamok differenciáldiagnózisa. In: Janszky J., Fogarasi A. (szerk.): Klinikai Epileptológia. Budapest, Medicina Könyvkiadó Zrt., 2017, 47-52.

[18] Faludi B.: Parasomniák. In: Köves P. (szerk.) Alvásmedicina: Alvás-ébrenléti zavarok ellátása háziorvosoktól az alváscentrumokig. Budapest, Bookmaker Kiadó, 2008.

[19] Derry, C.P. et al: Paroxysmal motor disorders of sleep: the clinical spectrum and differentiation from epilepsy. Epilepsia, 2006, 47: 1775-91. DOI: $10.1111 /$ j.15281167.2006.00631.x

[20] Faludi B.: Mozgás- és magatartászavarok alvásban. Praxis: a minőségi gyógyítás elmélete és gyakorlata. 2012, 21 (3): 39-50.

[21] Kotagal, P., Yardi, N.: The relationship between sleep and epilepsy. Semin. Pediatr. Neurol., 2008, 15: 42-49.

DOI: $10.1016 /$ j.spen.2008.03.007

[22] Chesson, Al. Jr., Ferber, R.A., Fry, J.M. et al.: The indications for polysomnography and related procedure. Sleep, 1997, 20: 423-87.
Col. Z. Szakács MDMC, PhD

The importance of parasomnias and sleep related epilepsies and their differential diagnostic procedures

The author presents sleep related movement disorders producing differential diagnostic problems, highlighted role parasomnias and sleep related epilepsies. Wide variety of the movements (from the physiologic body position changes to different pathologic events) can be seen during the sleep period. The most important types of these movements are the sleep related events (from the parasomnias to the restless leg related movements), the movement disorders and the epilepsy related events. To differentiate between these events is required special skill, which is based on appropriate characterisation of the events (for example timing, repetition, pattern), the polysomnographic and video-EEG examination and validated questionnaires (FLEP scale). The appropriate differential diagnostics and therapy must be based on the knowledge of the relationship of the sleep architecture and movement events. This review would like to provide guideline for the understanding and recognizing the nature of the sleep related movements.

Keywords: parasomnia, epilepsy, polisomnography, sleep related movement disorders

Dr. Szakács Zoltán o. ezds. 1134 Budapest, Róbert Károly krt. 44. 